\title{
Non-isothermal kinetics of the thermal desorption of mercury from a contaminated soil
}

\author{
Félix A. López ${ }^{\mathrm{a}, 凶}$, María José Sierra $^{\mathrm{b}}$, Olga Rodríguez ${ }^{\mathrm{a}}$, Rocío Millán $^{\mathrm{b}}$, Francisco J. Alguacil ${ }^{\mathrm{a}}$ \\ a Centro Nacional de Investigaciones Metalúrgicas (CENIM), CSIC. Avda. Gregorio del Amo 8, 28040 Madrid, Spain \\ ${ }^{b}$ Centro de Investigaciones Energéticas Medioambientales y Tecnológicas (CIEMAT) Avda. Complutense 22, 28230 Madrid, Spain \\ Corresponding author: flopez@cenim.csic.es
}

Submitted: 3 October 2013; Accepted: 11 November 2013

SUMMARY: The Almadén mining district (Ciudad Real, Spain) was the largest cinnabar (mercury sulphide) mine in the world. Its soils have high levels of mercury a consequence of its natural lithology, but often made much worse by its mining history. The present work examines the thermal desorption of two contaminated soils from the Almadén area under non-isothermal conditions in a $\mathrm{N}_{2}$ atmosphere, using differential scanning calorimetry (DSC). DSC was performed at different heating rates between room temperature and $600{ }^{\circ} \mathrm{C}$. Desorption temperatures for different mercury species were determined. The Friedman, Flynn-Wall-Ozawa and Coasts-Redfern methods were employed to determine the reaction kinetics from the DSC data. The activation energy and pre-exponential factor for mercury desorption were calculated.

KEYWORDS: Contaminated soils; DSC; Kinetic; Mercury; Thermal desorption

Citation / Cómo citar este artículo: López, F.A., Sierra, M.J., Rodríguez, O., Millán, R., Alguacil, F.J. (2014) “Nonisothermal kinetics of the thermal desorption of mercury from a contaminated soil". Rev. Metal. 50(1): 0001. doi: http://dx.doi.org/10.3989/revmetalm.001

RESUMEN: Estudio cinético, en condiciones no-isotérmicas, de la desorción térmica del mercurio en suelos contaminados. El distrito minero de Almadén (Ciudad Real, España) tiene la mayor mina de cinabrio (sulfuro de mercurio) del mundo. Sus suelos tienen altos niveles de mercurio como consecuencia de su litología natural, pero a menudo su contenido en mercurio es mucho más alto debido a la historia minera de la zona. Este trabajo examina la desorción térmica de dos suelos contaminados procedentes de Almadén bajo condiciones isotérmicas en atmósfera de $\mathrm{N}_{2}$, empleando calorimetría diferencial de barrido (DSC). La calorimetría se llevó a cabo a diferentes velocidades de calentamiento desde temperatura ambiente hasta $600{ }^{\circ} \mathrm{C}$. Se determinaron las diferentes temperaturas de desorción de las especies de mercurio presentes en los suelos. Para determinar la cinética de reacción a partir de los datos de DSC se utilizaron los métodos de Friedman, Flynn-Wall-Ozawa y Coasts-Redfern. Además se calcularon las energías de activación y los factores pre-exponenciales para la desorción del mercurio.

PALABRAS CLAVE: Cinética; Desorción térmica; DSC; Mercurio; Suelos contaminados

Copyright: (C) CSIC. This is an open-access article distributed under the terms of the Creative Commons AttributionNon Commercial (by-nc) Spain 3.0 License. 


\section{INTRODUCTION}

Mercury $(\mathrm{Hg})$ is one of the most toxic of global pollutants (Gochfeld, 2003). Its toxicity depends on the type of exposure suffered and the chemical species involved being organic forms the most toxic (Luciana et al., 2012). Bioaccumulation and biomagnification intensify its ecological and toxicological impacts (Luciana et al., 2012 and Fitzgerald and Lamborg, 2003).

The mining districts of Almadén (Spain), Idrija (Slovenia) and Monte Amiata (Italy) have together produced more than half of the total $\mathrm{Hg}$ extracted and commercialized in the world. Although operations have now ceased, Almadén was the world's largest and oldest $\mathrm{Hg}$ mining operation, its production making up a full one third of the total $\mathrm{Hg}$ ever extracted (Hylander and Meili, 2003). This activity led to the gradual dissemination and redistribution of $\mathrm{Hg}$ in the surrounding area. Millán et al., (2006) and Millán et al., (2011) report $\mathrm{Hg}$ to be present in concentrations of up to $40,000 \mathrm{mg} \mathrm{kg}^{-1}$ in the soils affected by mining activities. Even areas further away from the centres of exploitation were affected by the atmospheric and hydrological transport of $\mathrm{Hg}$ (Higueras et al., 2003).

In others countries, small-scale gold $(\mathrm{Au}) \mathrm{min}$ ing activities are harmful to the environment in part because of the widespread use of $\mathrm{Hg}$ in the extraction process. After thoroughly grinding $\mathrm{Au}$-containing ore or silt, $\mathrm{Hg}$ is added, creating an amalgam. Subsequent heating concentrates the gold into a pellet but releases elemental mercury into the environment (Paruchuri et al., 2010). In soil samples collected from the Tapajós (Brazil) gold mining reserve, the total mercury concentration in soil is nearly 13 times that recorded for background sites (Egler et al., 2006).

The technologies used to remove or stabilize $\mathrm{Hg}$ in contaminated solid waste or soil include solidification/stabilization, soil washing, thermal treatment, solar thermal desorption, vitrification and electrokinetic remediation. A comparison of the different technologies is provided by Wang et al. (2012) and López-Delgado et al. (2012a and 2012b) the Resource Conservation and Recovery Act (RCRA) of the United States suggests that Hg-containing waste be treated by solidification/stabilization when the $\mathrm{Hg}$ content is less than $260 \mathrm{mg} \mathrm{kg}{ }^{-1}$, and that thermal desorption methods be used when the $\mathrm{Hg}$ values are higher than $260 \mathrm{mg} \mathrm{kg}^{-1}$ (USEPA, 2008).

Thermal desorption treatment usually involves an ex situ technology that converts mercurial compounds into volatile $\mathrm{Hg}$. The safety and reduced emissions due to the use of suitable filters associated with these techniques have led to their becoming preferred technologies in this field (Chang and Yen, 2006). Hg thermal desorption experiments have demonstrated the feasibility of mercury removal at
TABLE 1. Desorption temperatures of different mercury phases in contaminated soils (Kunkel et al., 2006 and Biester et al., 2000)

\begin{tabular}{lc}
\hline Phase & $\begin{array}{c}\text { Desorption temperature of } \\
\text { phase } \mathbf{~ H g}\left({ }^{\circ} \mathbf{C}\right)\end{array}$ \\
\hline $\mathrm{Hg}^{0}$ & $<100$ \\
$\mathrm{Non} \mathrm{Cinnabar} \mathrm{Hg}$ & $150-250$ \\
$\mathrm{Hg}_{2} \mathrm{Cl}_{2}$ & $<180$ \\
$\mathrm{HgCl}_{2}$ & $<250$ \\
$\mathrm{HgS}(\mathrm{Cinnabar})$ & $310-350$ \\
$\mathrm{HgO}$ & $420-550$ \\
$\mathrm{HgSO}$ & $450-500$ \\
$\mathrm{Hg}$ in Pyrite & $>450$ \\
$\mathrm{Hg}$ in Sphalerite & 600 \\
\hline
\end{tabular}

temperatures between $127^{\circ} \mathrm{C}$ and $600{ }^{\circ} \mathrm{C}$ (Kunkel et al., 2006).

Thermal decomposition techniques have been used to identify $\mathrm{Hg}$ compounds in soil, sediment samples, iron-based sorbents, and even in $\mathrm{Hg}$ lamp waste. The $\mathrm{Hg}$ species thermally released from contaminated soils can be analysed in several ways, including temperature-controlled continuous heating of samples in a furnace coupled to an atomic absorption spectrophotometer (AAS) (Windmoller et al., 1996) the use of solid-phase Hg-thermodesorption techniques complemented by selective extraction of organically bound $\mathrm{Hg}$ (Biester et al., 2000 ) by temperature programmed decomposition desorption (TPDD) (Ozaki et al., 2008), or by pyrolysis and X-ray absorption fine spectroscopy (XAFS) (Liu et al., 2006). Table 1 shows the mercury speciation derivatives recorded by different researchers.

In the present work, the thermal desorption of $\mathrm{Hg}$ was analyzed by differential scanning calorimetry (DSC) in a $\mathrm{N}_{2}$ atmosphere, with the aim of elucidating the associated reaction mechanisms and kinetics.

\section{MATERIALS AND METHODS}

\subsection{Samples}

The material analysed consisted of two $\mathrm{Hg}$ contaminated soils (S1 and S2) from the Almadén area (Fig. 1). Soil S1 (34 mg kg-1 of total $\mathrm{Hg}$ ) was taken from Dehesa de Castilseras (northeast of the El Entredicho mine). The area is an open Mediterranean forest where livestock graze. The $\mathrm{Hg}$ concentration of this soil is lower than the other soil $\mathrm{S} 2$ (Table 2) and is mainly of natural origin although this site has also been affected by mining activity. Soil S2 $\left(10,497 \mathrm{mg} \mathrm{kg}^{-1}\right.$ of total $\left.\mathrm{Hg}\right)$ was from an abandoned metallurgical site in Almadenejos. This site dates from the 18 th century and lies $12 \mathrm{~km}$ from 


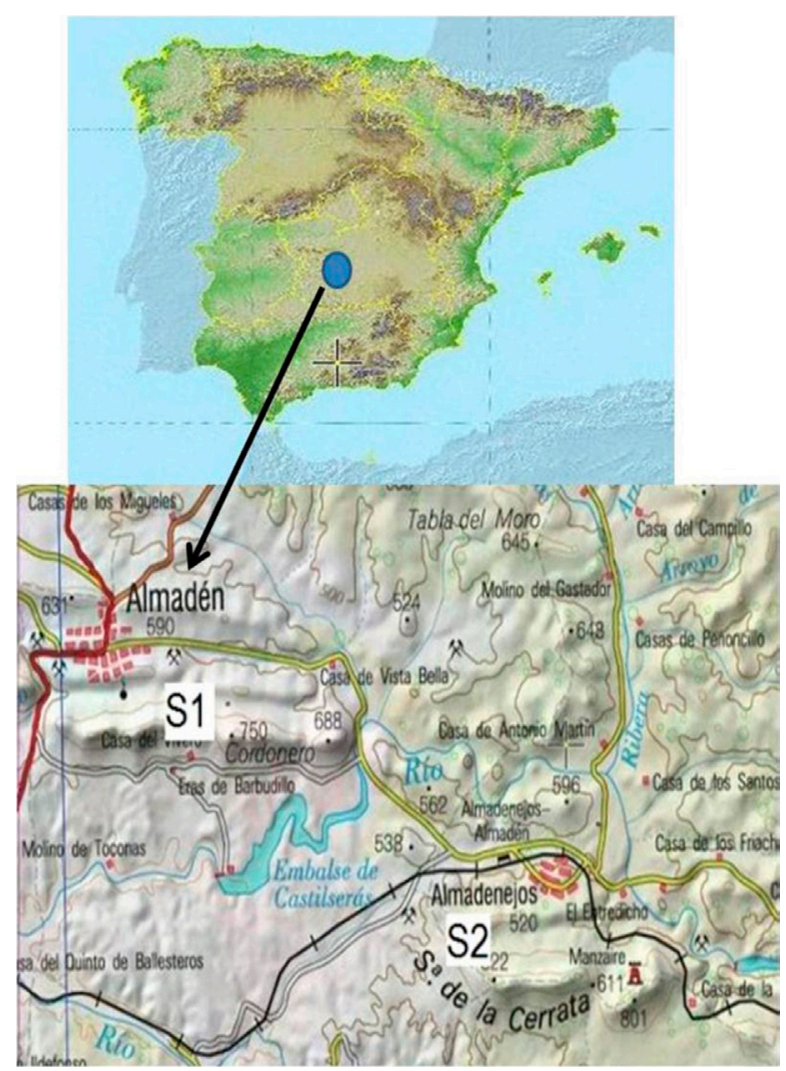

FIGURE 1. Location of soil collection sites.

Almadén. It occupies an area of some $30,000 \mathrm{~m}^{2}$ and is surrounded by a wall built between 1756 and 1759. The area contains six pairs of abandoned roasting furnaces once used to obtain primary $\mathrm{Hg}$ from cinnabar. The soil in this area has a high $\mathrm{Hg}$ concentration (Table 2) - partly of natural origin and partly the result of mining activity, $\mathrm{Hg}$ waste storage, and the use of these cinnabar roasting furnaces (Millán et al., 2011). As sampling strategy, a composite sample of each study soil was collected from a $5 \mathrm{~m}^{2}$ by obtaining $10 \mathrm{~cm}$ of the surface soil at five points. Afterwards, both soil samples were air dried and sieved to obtain the fraction less than $2 \mathrm{~mm}$ ready for the different analysis and trials.

Furthermore, reference materials with known concentrations of $\mathrm{Hg}$ were used: CRM 051 from an $\mathrm{Hg}$-contaminated area $\left(29.9 \pm 5.96 \mathrm{mg} \mathrm{kg}^{-1}\right.$ of total $\mathrm{Hg}$ ) in the western USA, and SRM 2709a, an agricultural soil $\left(1.40 \pm 0.08 \mathrm{mg} \mathrm{kg}^{-1}\right.$ of total $\left.\mathrm{Hg}\right)$ from San Joaquín (Querétaro, Mexico).

\subsection{Physico-chemical analysis of soils}

The $\mathrm{pH}\left(\mathrm{H}_{2} \mathrm{O}, 1: 2.5\right)$ and electrical conductivity (EC) $\left(\mathrm{H}_{2} \mathrm{O}, 1: 5\right)$ of the soils were measured according to the official methods of the Spanish Ministry of Agriculture, Fisheries and Food (MAPA, 1994). The EC of the saturated extract $(\mathrm{EC})_{\mathrm{ES}}$ was determined by multiplying EC by 6.4 according to the method proposed by Loveday et al., (1972). The organic matter $(\mathrm{OM})$ content of the soils was determined using the method of Walkley-Black and the soil textures recorded using the Bouyoucos method, according to standard procedures (Page et al., 1987).

\subsection{Determination of soil $\mathrm{Hg}$ concentration}

The $\mathrm{Hg}$ concentration of the soil samples was directly measured using an atomic absorption spectrophotometer specifically designed for $\mathrm{Hg}$ determination (Advanced Mercury Analyser - AMA254 - LECO Company). The certified reference material CRM 051 (soil from USA contaminated area, $29.90 \pm 5.96 \mathrm{mg} \mathrm{kg}^{-1}$ of total $\mathrm{Hg}$ ) was used as a standard to determine the accuracy and precision of the measurements and to validate the applied method. The mean value of total $\mathrm{Hg}$ determined for 10 measurements of the certified material using the AMA254 equipment was $29.90 \pm 2.89 \mathrm{mg} \mathrm{kg}^{-1}$ of total $\mathrm{Hg}$. At a 95\% confidence level, no significant differences were detected between the certified value and the experimental one, this method was therefore considered to be reliable for the determination of total $\mathrm{Hg}$.

When samples showed a high $\mathrm{Hg}$ content, out of equipment range limit (>600 ng), they were preprocessed by an acidic digestion using a MARS5 microwave oven (VERTEX Technics) following EPA Method 3052 (USEPA, 1996) in order to dilute for measuring by the above analyser. Recovery percentage for certified reference material (CRM 051) was $99 \%$.

Table 2 shows the physico-chemical characteristics of the contaminated and reference soils.

TABle 2. Physico-chemical characteristics of contaminated soils

\begin{tabular}{|c|c|c|c|c|c|c|}
\hline Soil & pH & 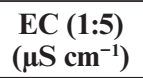 & $\underset{\left(\mathrm{dS} \mathrm{cm}^{-1}\right)}{\mathrm{EC}_{\mathrm{S}}}$ & $\begin{array}{c}\text { Organic } \\
\text { Matter (wt. \%) }\end{array}$ & Texture & $\begin{array}{c}\mathrm{Hg} \\
\left(\mathrm{mg} \mathrm{kg}^{-1}\right)\end{array}$ \\
\hline S1 & 6.9 & 164 & 1.05 & 2.8 & Sandy loam & $34.40 \pm 7.20$ \\
\hline $\mathrm{S} 2$ & 6.1 & 614 & 3.93 & 3.7 & Sandy loam & $10,497 \pm 1,564$ \\
\hline SRM 2709a & - & - & - & - & - & $1.40 \pm 0.08$ \\
\hline CRM 051 & - & - & - & - & - & $29.90 \pm 5.96$ \\
\hline
\end{tabular}




\subsection{Thermal desorption study soil constituents}

S1, S2, CRM 051 and SRM 2709a were subjected to DSC analysis in a $\mathrm{N}_{2}$ atmosphere (flow

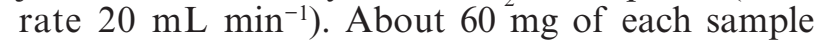
were placed in a $175 \mu \mathrm{L}$ sealed aluminium crucible and heated at a rate of $10^{\circ} \mathrm{C} \mathrm{min}-1$ between 25 and $600{ }^{\circ} \mathrm{C}$ or $650{ }^{\circ} \mathrm{C}$ in a Setaram Model 3D-EVO analyser, which also recorded the temperature peaks associated with $\mathrm{Hg}$ desorption.

\subsection{Differential scanning calorimetry kinetics: Mathematical models for determining $\mathbf{H g}$ desorption kinetics}

The kinetics of $\mathrm{Hg}$ desorption were then studied by DSC using the apparatus mentioned above. DSC experiments were performed at four different heating

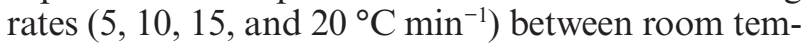
perature and $600{ }^{\circ} \mathrm{C}$. Temperature calibration was achieved using ICTAC-recommended DSC standards. The accuracy of the reported temperatures was estimated to be $\pm 2{ }^{\circ} \mathrm{C}$. The sample mass used was again about $60 \mathrm{mg}$, and all experiments were performed in a $\mathrm{N}_{2}$ atmosphere (flow rate $20 \mathrm{~mL} \mathrm{~min}^{-1}$ ).

For mercury desorption, it is generally assumed that the rate of conversion is proportional to the concentration of reacted material. The rate of conversion can be expressed by the following basic rate equation (Eq. 1):

$$
\frac{d \alpha}{d t}=\beta \frac{d \alpha}{d T}=k(T) . f(\alpha)
$$

where $\alpha$ is the degree of advance of reaction, $f(\alpha), \beta$ the heating rate $\left({ }^{\circ} \mathrm{C} \mathrm{min}^{-1}\right)$ and $k(T)$ are functions of conversion and temperature. For the DSC experiments, equation (2) can be expressed as:

$$
\frac{d \alpha}{d t}=\frac{d H}{d t} \cdot \frac{1}{\Delta H \text { total }}
$$

where $\frac{d H}{d t}$ is the heat flow above baseline and $\Delta H$ total the peak area of the reaction, expressed in $\mathrm{mJ}$.

By combining equations (1) and (2), the rate of conversion can be written in the form Eq. (3):

$$
\frac{d \alpha}{d t}=\frac{d H}{d t} \cdot \frac{1}{\Delta \text { Htotal }}=k(T) \cdot f(\alpha)
$$

where $k(T)$ is the temperature dependent on the rate of heat flow; this is often modelled successfully by the Arrhenius Eq. (4):

$$
k(T)=A e^{-E / R T}
$$

where $E(\mathrm{~kJ} / \mathrm{mol})$ is the activation energy, $A\left(\mathrm{~min}^{-1}\right)$ the pre-exponential factor, and $\mathrm{R}$
(8.314 $\mathrm{J} \mathrm{mol}^{-1} \mathrm{~K}^{-1}$ ) the gas constant. By combining equations (3) and (4), the reaction rate can be written as Eq. (5):

$$
\frac{d \alpha}{d t}=A e^{-E / R T} f(\alpha)
$$

\section{Friedman method}

Friedman analysis (Friedman, 1964), which is based on the Arrhenius equation (4), takes into account the logarithm of the conversion rate $(d \alpha / d t)$ as a function of the reciprocal of the temperature (i.e., $1 / T)$ at different degrees of conversion $\alpha$, according to Eq. (6):

$$
\left.\ln \frac{d \alpha}{d t}\right|_{\alpha i}=\ln \left(A_{i} f\left(\alpha_{i, j}\right)\right)-\frac{E_{a i}}{R \cdot T_{i, j}}
$$

where $i$ is the index of conversion, $j$ is the curve index, $E_{a}$ the apparent activation energy at $\alpha_{i}$, and $f\left(\alpha_{i, j}\right)$ the function dependent on the reaction model (assumed to be constant for a given reaction progress $\alpha_{i, j}$ for all curves $j$ ). Since $f(\alpha)$ is constant at each degree of conversion $\alpha i$, the curve for the logarithm of the reaction rate vs. $1 / T$ is linear, with a slope of $E_{a} / R$ and an intercept $A$.

\section{Flynn-Wall-Ozawa method}

The Flynn-Wall-Ozawa method (Flynn and Wall, 1996 and Ozawa, 1965) is derived from the integral isoconversional method. Using Doyle's approximation (Doyle, 1961) the reaction rate in logarithmic form can be expressed as Eq. (7):

$$
\ln \beta=\ln \left(\frac{A E_{a}}{R \cdot g(\alpha)}\right)-5.331-1.052 \frac{E_{a}}{R} \frac{1}{T}
$$

where $\beta$ is the heating rate and $g(\alpha)$ is the function of conversion. Thus, for any constant $\alpha$ value, the plot $\ln \beta$ vs. $1 / T$ recorded at different heating rates should be a straight line. The $E_{a}$ can be then determined from its slope.

\section{Coats-Redfern method}

The Coats-Redfern method (Coats and Redfern, 1964) provides the thermal decomposition mechanism from the mass loss. An asymptotic approximation of $2 \mathrm{RT} / \mathrm{E}_{\mathrm{a}}<1$ for the resolution of Eq. (8):

$$
\begin{aligned}
g(\alpha) & =\int_{0}^{\alpha} \frac{d \alpha}{f(\alpha)}=\frac{A}{\beta} \int_{T_{0}}^{T} \exp \left(\frac{{ }^{E} a}{R T}\right) d T \\
& =\frac{A E_{a}}{\beta R} p\left(\frac{{ }^{E} a}{R T}\right)
\end{aligned}
$$


TABLE 3. Algebraic expressions of functions of the most common reaction mechanisms

\begin{tabular}{|c|c|c|}
\hline Mechanism & $f(\alpha)$ & $g(\alpha)$ \\
\hline Autocatalytic & $(1-\alpha)^{\mathrm{n}} \cdot \alpha^{\mathrm{m}}$ & - \\
\hline $\begin{array}{l}\text { Avarani-Erofe've } \\
\text { (A1.5) }\end{array}$ & $1.5(1-\alpha)[-\ln (1-\alpha)]^{1 / 3}$ & {$[-\ln (1-\alpha)]^{1 / 3}$} \\
\hline $\begin{array}{l}\text { Avarani-Erofe've } \\
\text { (A2) }\end{array}$ & $2(1-\alpha)[-\ln (1-\alpha)]^{1 / 2}$ & {$[-\ln (1-\alpha)]^{1 / 2}$} \\
\hline $\begin{array}{l}\text { Avarani-Erofe've } \\
\text { (An) }\end{array}$ & $\mathrm{n}(1-\alpha)[-\ln (1-\alpha)]^{(1-1 / n)}$ & {$[-\ln (1-\alpha)]^{(1-1 / n)}$} \\
\hline First-order (F1) & $(1-\alpha)$ & $-\ln (1-\alpha)$ \\
\hline $\begin{array}{l}\text { Second-order } \\
\quad \text { (F2) }\end{array}$ & $(1-\alpha)^{2}$ & $(1-\alpha)^{-1}-1$ \\
\hline Third-order (F3) & $(1-\alpha)^{3}$ & {$\left[(1-\alpha)^{-2}-1\right] / 2$} \\
\hline $\begin{array}{l}\text { Contracting } \\
\text { sphere (R2) }\end{array}$ & $2(1-\alpha)^{1 / 2}$ & {$\left[1-(1-\alpha)^{1 / 2}\right]$} \\
\hline $\begin{array}{l}\text { Contracting } \\
\quad \text { Cylinder (R3) }\end{array}$ & $3(1-\alpha)^{2 / 3}$ & {$\left[1-(1-\alpha)^{1 / 3}\right]$} \\
\hline Power law (P2) & $2 \alpha^{1 / 2}$ & $\alpha^{1 / 2}$ \\
\hline Power law (P3) & $3 \alpha^{2 / 3}$ & $\alpha^{1 / 3}$ \\
\hline Power law (P4) & $4 \alpha^{3 / 4}$ & $\alpha^{1 / 4}$ \\
\hline $\begin{array}{l}\text { One-dimensional } \\
\text { diffusion (D1) }\end{array}$ & $1 / 2 \alpha$ & $\alpha^{2}$ \\
\hline $\begin{array}{l}\text { Two-dimensional } \\
\text { diffusion (D2) }\end{array}$ & {$[-\ln (1-\alpha)]^{-1}$} & {$[(1-\alpha) \ln (1-\alpha)]+\alpha$} \\
\hline $\begin{array}{l}\text { Three- } \\
\text { dimensional } \\
\text { diffusion (D3) }\end{array}$ & $\begin{array}{c}\left.3(1-\alpha)^{(2 / 3)}\right] / \\
{\left[2\left(1-(1-\alpha)^{(1 / 3)}\right)\right]}\end{array}$ & {$\left[1-(1-\alpha)^{1 / 3}\right]^{2}$} \\
\hline $\begin{array}{l}\text { Giustling- } \\
\text { Brounsthein (D4) }\end{array}$ & $1.5\left((1-\alpha)^{(-1 / 3)}-1\right)$ & $1-(2 \alpha / 3)-(1-\alpha)^{2 / 3}$ \\
\hline
\end{tabular}

allows equation (9) to be obtained:

$\ln \frac{g(\alpha)}{T^{2}}=\ln \frac{A R}{\beta E}-\frac{E_{a}}{R T}$
The Coats-Redfern method is one of the most widely used procedures for the determination of reaction processes. The $E_{a}$ at a constant heating rate for any of the $g(\alpha)$ functions listed in Table 3 can be obtained from equation (9).

\section{RESULTS}

\subsection{Thermal decomposition of contaminated and reference soils}

Figure 2 shows the DSC curves by heating the soils at a rate of $10{ }^{\circ} \mathrm{C} \mathrm{min}^{-1}$ from room temperature to $650^{\circ} \mathrm{C}$. Two or three endothermic peaks can be seen. Table 4 shows the temperature data for these peaks.

Three peaks can be seen for S1, with maximum temperatures $\left(\mathrm{T}_{\mathrm{m}}\right)$ of $109.5{ }^{\circ} \mathrm{C}, 304.8{ }^{\circ} \mathrm{C}$ and $533.8{ }^{\circ} \mathrm{C}$. S2 has only two peaks of $\mathrm{T}_{\mathrm{m}} 121.8^{\circ} \mathrm{C}$ and $305.7{ }^{\circ} \mathrm{C}$.

CRM 051 has two peaks of $\mathrm{T}_{\mathrm{m}} 93.4^{\circ} \mathrm{C}$ and $546.4^{\circ} \mathrm{C}$, while SRM 2079a has three of $\mathrm{T}_{\mathrm{m}} 122.5^{\circ} \mathrm{C}, 279.2^{\circ} \mathrm{C}$ and $528.5^{\circ} \mathrm{C}$.

Using the data in Table 1 as a reference, $\mathrm{Hg}$ is released from $\mathrm{HgCl}_{2}$ between 72 and $182^{\circ} \mathrm{C}$, according to the reaction $\mathrm{HgCl}_{2}(\mathrm{~s}) \rightarrow \mathrm{Hg}(\mathrm{g})+2 \mathrm{Cl}(\mathrm{g})$ (peak 1 in the DSC curves; see Fig. 2). In a well-aerated soil as is the case of the study soils, the conditions are normally appropriate for the formation of inorganic $\mathrm{Hg}^{2+}$ as $\mathrm{HgCl}_{2}$. The mercurous cation is rarely stable under ambient conditions and, together with $\mathrm{Hg}^{0}$ is easily oxidized to $\mathrm{Hg}^{2+}$. Therefore, $\mathrm{Hg}$ form mainly present in the soil will be $\mathrm{HgCl}_{2}$ (Adriano, 2001 and Gaona, 2004).

The peak of $\mathrm{T}_{\mathrm{m}}=93.4{ }^{\circ} \mathrm{C}$ in the DSC curve for CRM 051 could be due to the desorption of

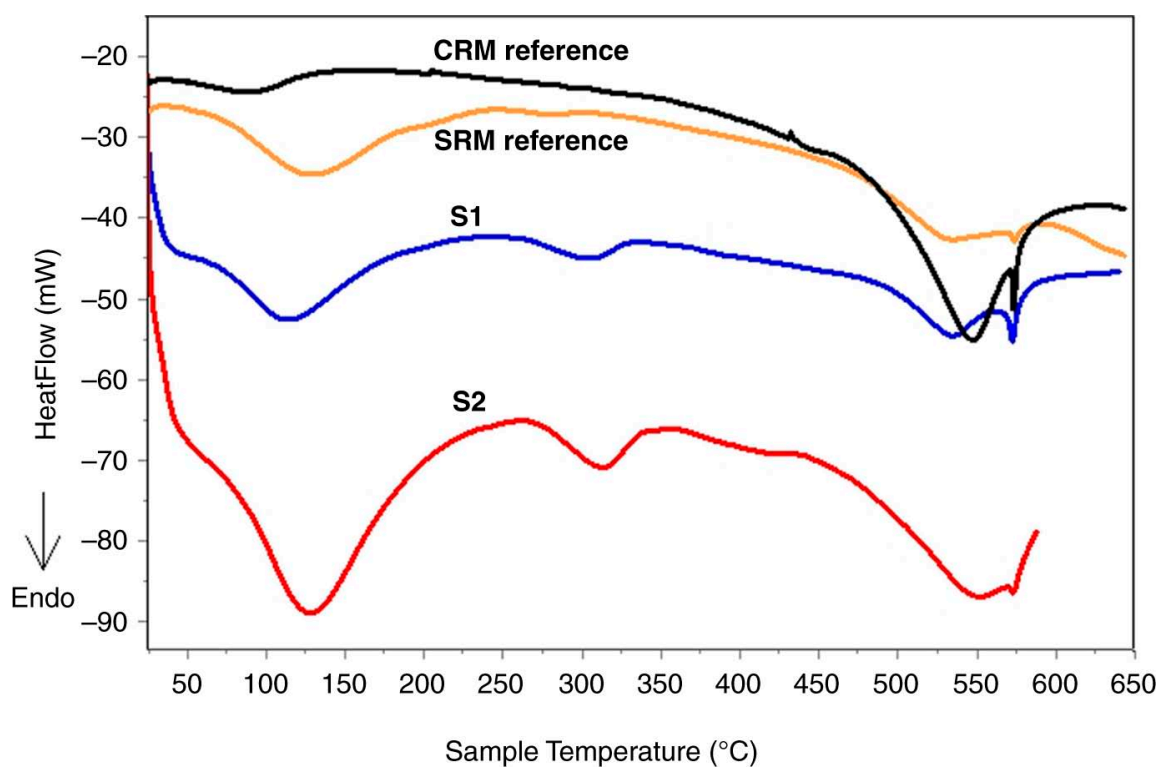

FIGURE 2. DSC curves of thermal decomposition of contaminated soils and references (Heating rate: $10^{\circ} \mathrm{C} \mathrm{min}^{-1}$ ). 
TABLE 4. DSC results for the thermal desorption of $\mathrm{Hg}$ from the contaminated and references soils (heating rate: $10^{\circ} \mathrm{C} \min ^{-1}$ )

\begin{tabular}{|c|c|c|c|c|c|c|c|c|c|}
\hline \multirow[b]{2}{*}{ Soil } & \multicolumn{3}{|c|}{ Peak 1} & \multicolumn{3}{|c|}{ Peak 2} & \multicolumn{3}{|c|}{ Peak 3} \\
\hline & $\mathrm{T}_{0}\left({ }^{\circ} \mathrm{C}\right)$ & $\mathbf{T}_{\mathrm{m}}\left({ }^{\circ} \mathbf{C}\right)$ & $\mathrm{T}_{\mathrm{e}}\left({ }^{\circ} \mathrm{C}\right)$ & $\mathrm{T}_{0}\left({ }^{\circ} \mathrm{C}\right)$ & $\mathbf{T}_{\mathrm{m}}\left({ }^{\circ} \mathbf{C}\right)$ & $\mathrm{T}_{\mathrm{e}}\left({ }^{\circ} \mathrm{C}\right)$ & $\mathrm{T}_{0}\left({ }^{\circ} \mathrm{C}\right)$ & $\mathrm{T}_{\mathrm{m}}\left({ }^{\circ} \mathrm{C}\right)$ & $\mathrm{T}_{\mathrm{e}}\left({ }^{\circ} \mathrm{C}\right)$ \\
\hline S1 & 74.3 & 109.5 & 141.3 & 266.7 & 304.8 & 327.2 & 506.4 & 533.8 & 554.8 \\
\hline $\mathrm{S} 2$ & 72.3 & 121.8 & 182.1 & 269.0 & 305.7 & 330.0 & - & - & - \\
\hline SRM & 78.0 & 122.5 & 172.5 & 265.3 & 279.2 & 296.2 & 505.6 & 528.5 & 559.5 \\
\hline CRM & 50.6 & 93.4 & 127.8 & - & - & - & 512.8 & 546.4 & 564.5 \\
\hline
\end{tabular}

$\left(\mathrm{T}_{\mathrm{o}}:\right.$ Start of peak temperature; $\mathrm{T}_{\mathrm{m}}:$ maximun temperature; $\mathrm{T}_{\mathrm{e}}:$ End of peak temperature)

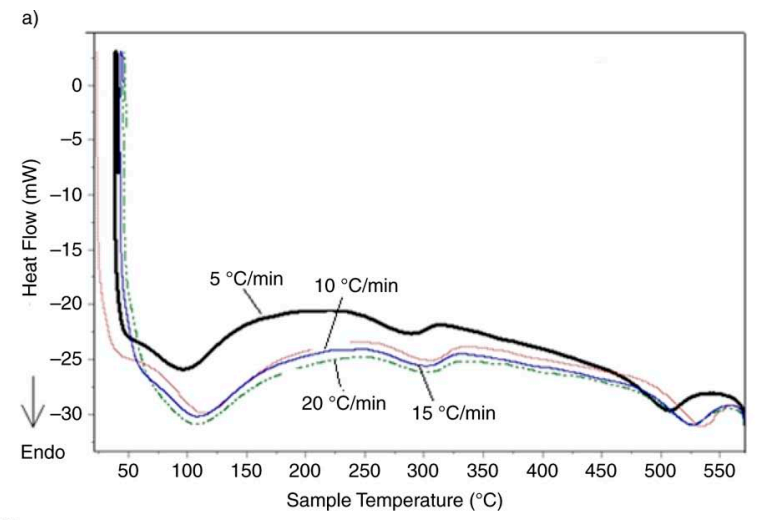

b)

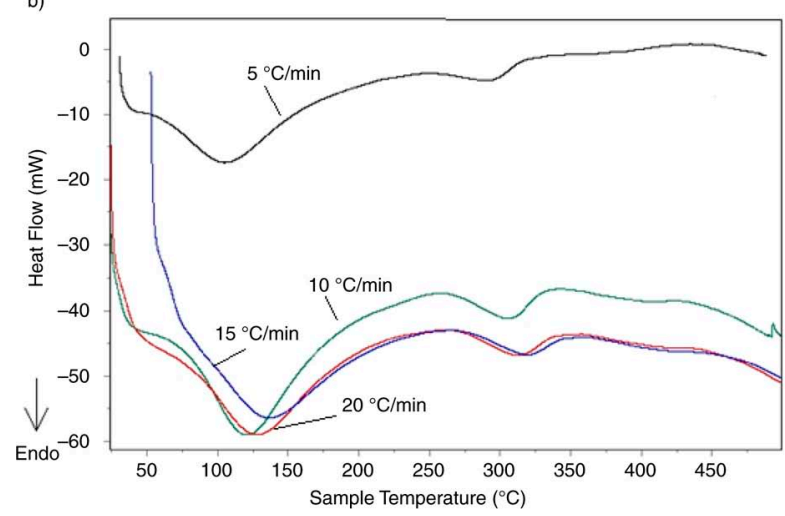

FIGURE 3. DSC curves for the decomposition of contaminated soils at different heating rates. a) for $\mathrm{S} 1$ and b) for $\mathrm{S} 2$. metallic $\mathrm{Hg}\left(\mathrm{Hg}^{0}\right)$, according to the reaction $\mathrm{Hg}^{0}(\mathrm{~s}) \rightarrow \mathrm{Hg}(\mathrm{g})$. This peak is not seen in any other DSC curve.

The decomposition of cinnabar $(\mathrm{HgS})$ occurs between 267 and $327^{\circ} \mathrm{C}$, according to the reaction $\mathrm{HgS}(\mathrm{s}) \rightarrow \mathrm{Hg}(\mathrm{g})+\mathrm{S}(\mathrm{g})$ (peak 2 in the DSC curves; see Fig. 2).

Finally, $\mathrm{HgO}$ decomposes at $505-565^{\circ} \mathrm{C}$ according to the reaction $\mathrm{HgO}(\mathrm{s}) \rightarrow \mathrm{Hg}(\mathrm{g})+1 / 2 \mathrm{O}_{2}(\mathrm{~g})$ (peak 3 in the DSC curves; see Fig. 2).

The $T_{m}$ values for desorption of $\mathrm{Hg}$ from the different $\mathrm{m}$ phases of the contaminated soils follow the order $\mathrm{Hg}^{0}<\mathrm{HgCl}_{2}<\mathrm{HgS}<\mathrm{HgO}$. These temperatures agree quite well with those reported by other authors using other techniques (Windmoller, 1996 and López et al., 2010). This order suggests that the thermal release of mercury species is related to its vapour pressure (Stein et al., 1996). When the vapour pressure decreases, the $\mathrm{Hg}$ release temperature increases.

$\mathrm{Hg}$ is subject to a wide array of chemical and biological transformation processes, such as $\mathrm{Hg}^{0}$ oxidation, $\mathrm{Hg}^{2+}$ reduction, and methylation, depending on the soil $\mathrm{pH}$, temperature, and humus content. The formation of organic $\mathrm{Hg}^{2+}$ complexes is known to be a dominant process, largely due to the affinity of $\mathrm{Hg}^{2+}$ and its inorganic compounds for sulphur-containing functional groups (Skyllberg et al., 2006).

TABLE 5. DSC data for the thermal decomposition of the soils at different heating rates

\begin{tabular}{|c|c|c|c|c|c|c|c|c|c|}
\hline \multirow[b]{2}{*}{$\beta\left({ }^{\circ} \mathrm{C}\right.$ min $\left.^{-1}\right)$} & \multicolumn{3}{|c|}{ Peak 1} & \multicolumn{3}{|c|}{ Peak 2} & \multicolumn{3}{|c|}{ Peak 3} \\
\hline & $\mathrm{T}_{0}\left({ }^{\circ} \mathrm{C}\right)$ & $\mathrm{T}_{\mathrm{m}}\left({ }^{\circ} \mathrm{C}\right)$ & $\overline{T_{e}\left({ }^{\circ} \mathrm{C}\right)}$ & $\mathrm{T}_{\mathrm{o}}\left({ }^{\circ} \mathrm{C}\right)$ & $\mathrm{T}_{\mathrm{m}}\left({ }^{\circ} \mathrm{C}\right)$ & $\mathrm{T}_{\mathrm{e}}\left({ }^{\circ} \mathrm{C}\right)$ & $\mathrm{T}_{\mathrm{o}}\left({ }^{\circ} \mathrm{C}\right)$ & $\mathrm{T}_{\mathrm{m}}\left({ }^{\circ} \mathrm{C}\right)$ & $\mathrm{T}_{\mathrm{e}}\left({ }^{\circ} \mathrm{C}\right)$ \\
\hline \multicolumn{10}{|l|}{ S1 } \\
\hline 5 & 60.8 & 95.1 & 122.7 & 251.6 & 284.9 & 309.0 & 493.1 & 507.6 & 524.2 \\
\hline 10 & 74.3 & 109.5 & 142.3 & 266.7 & 304.8 & 327.2 & 495.0 & 526.0 & 549.7 \\
\hline 15 & 74.9 & 110.9 & 149.7 & 261.7 & 300.9 & 325.8 & 566.9 & 572.3 & 575.9 \\
\hline 20 & 73.5 & 108.6 & 151.6 & 262.6 & 301.0 & 324.6 & 564.2 & 572.1 & 577.9 \\
\hline \multicolumn{10}{|l|}{$\mathrm{S} 2$} \\
\hline 5 & 61.5 & 103.6 & 141.5 & 260.6 & 294.1 & 314.3 & - & - & - \\
\hline 10 & 72.3 & 121.8 & 146.7 & 269.0 & 305.7 & 330.0 & - & - & - \\
\hline 15 & 85.7 & 122.5 & 149.4 & 274.8 & 312.3 & 335.9 & - & - & - \\
\hline 20 & 96.9 & 129.8 & 154.3 & 279.2 & 318.2 & 343.0 & - & - & - \\
\hline
\end{tabular}


TABLE 6. Activation energies for S1 and S2, as determined by the Friedman and the Flynn-Wall-Ozawa methods

\begin{tabular}{|c|c|c|c|c|}
\hline \multirow[b]{2}{*}{ Peak / Reaction } & \multirow[b]{2}{*}{ Soil } & \multicolumn{2}{|c|}{$\begin{array}{c}\text { FR } \\
\text { method }\end{array}$} & \multirow{2}{*}{$\begin{array}{c}\begin{array}{c}\text { FWO } \\
\text { method }\end{array} \\
\text { Ea }\left(\mathrm{kJ} \mathrm{mol}^{-1}\right)\end{array}$} \\
\hline & & $\mathrm{Ea}\left(\mathrm{kJ} \mathrm{mol}^{-1}\right)$ & $A\left(s^{-1}\right)$ & \\
\hline $\begin{array}{l}\text { Peak 1: } \\
\mathrm{HgCl}_{2} \rightarrow \mathrm{Hg}(\mathrm{g})+2 \mathrm{Cl}(\mathrm{g})\end{array}$ & $\begin{array}{l}\text { S1 } \\
\text { S2 }\end{array}$ & $\begin{array}{l}44.6 \pm 3.9 \\
49.7 \pm 3.0\end{array}$ & $\begin{array}{l}7.74 \times 10^{3} \\
1.54 \times 10^{4}\end{array}$ & $\begin{array}{l}53.0 \pm 4.8 \\
55.7 \pm 3.3\end{array}$ \\
\hline $\begin{array}{l}\text { Peak 2: } \\
\mathrm{HgS} \rightarrow \mathrm{Hg}(\mathrm{g})+\mathrm{S}(\mathrm{g}) \\
\text { Peak 3: } \\
\mathrm{HgO} \rightarrow \mathrm{Hg}(\mathrm{g})+1 / 2 \mathrm{O}_{2}(\mathrm{~g})\end{array}$ & $\begin{array}{l}\text { S1 } \\
\text { S2 } \\
\text { S1 } \\
\text { S2 }\end{array}$ & $\begin{array}{l}138.6 \pm \\
188.7 \pm 9.8 \\
255.2 \pm \\
\quad-\end{array}$ & $\begin{array}{l}4.73 \times 10^{10} \\
1.01 \times 10^{15} \\
5.95 \times 10^{14} \\
-\end{array}$ & $\begin{array}{l}145.0 \pm 7.6 \\
186.7 \pm 12.3 \\
284.4 \pm 2.7 \\
\quad-\end{array}$ \\
\hline
\end{tabular}

Besides the above mentioned peaks, all samples show a sharp endothermic peak at $575^{\circ} \mathrm{C}$, that could be attributed to the polymorphic transformation of hypothermic quartz to hyperthermic quartz which starts at this temperature. It is due to the phase transition in quartz ( $\alpha$-Quartz trigonal to $\beta$-Quartz hexagonal) (Karathanasis et al., 1994; Plante et al., 2009; Salgado et al., 1995 and Salgado et al., 2004). X-ray diffraction of soil samples shows that the percentage of quartz in soil S1 $(82 \%)$ is higher than the soil S2 $(60 \%)$. This result is in agreement with the different depth of the S1 and S2 peaks. Thereby, the peak of S1 is deeper than the peak of S2.

Figure 3 show the DSC curves for S1 and S2 at different heating rates $\left(5,10,15\right.$ and $\left.20 \mathrm{~K} \mathrm{~min}^{-1}\right)$. Table 5 shows the $T_{m}$ values for the peaks obtained. A shift towards higher $\mathrm{T}$ values was seen as the heating rate increased (Fig. 3). This displacement of DSC curves with heating rate has been described by other researchers (Aboulkas et al., 2010).

Both soils present the same two firs peaks showing similar chemical bonds. However soil S1 has a third peak which does not appear in the case of S2. Therefore, $\mathrm{S} 1$ seems to have significantly more $\mathrm{HgO}$ than $\mathrm{S} 2$ has.

\subsection{Calculation of the activation energy}

The Friedman (FR) and the Flynn-Wall-Ozawa (FWO) methods were first used to calculate the $E_{a}$ for all heating rates.

With the FR method, the $E_{a}$ was calculated for different conversion values by plotting $\ln (d \alpha / d T)$ against $1 / T$ for a constant $\alpha$ value. Table 6 shows the results for $\mathrm{S} 1$ and $\mathrm{S} 2$.

Equation (7) was used with the FWO method. The results supplied are independent of the degradation mechanism. The $E_{a}$ for $\mathrm{S} 1$ and $\mathrm{S} 2$ were obtained from the plot of $\log (\beta)$ vs. $1 / T$ at a fixed conversion rate (the slope being $0.4567 \mathrm{E} / \mathrm{R}$ ). Table 6 shows the $E_{a}$ values for S1 and S2.

The $E_{a}$ values obtained with the FWO method were higher than those obtained by the FR method. This is to be expected since the FWO method involves a systematic error that does not affect the FR method (Vyazovkin, 2001). The $E_{a}$ values obtained by the FR method are therefore deemed more reliable.
For all the decomposition reactions studied, the variation in $E_{a}$ with the degree of conversion over the interval $0.1<\alpha<0.9$ was practically constant (Figure 4). This suggests that these Hg reactions occur in a single stage.

The variation in $E_{a}$, independent of the calculation method used, shows that $E_{a} \mathrm{HgCl}_{2}<E_{a}$ $\mathrm{HgS}<E_{a} \mathrm{HgO}$. The vapour pressure and decomposition $\mathrm{T}_{\mathrm{m}}$ values for each $\mathrm{Hg}$ compound follow the same order.

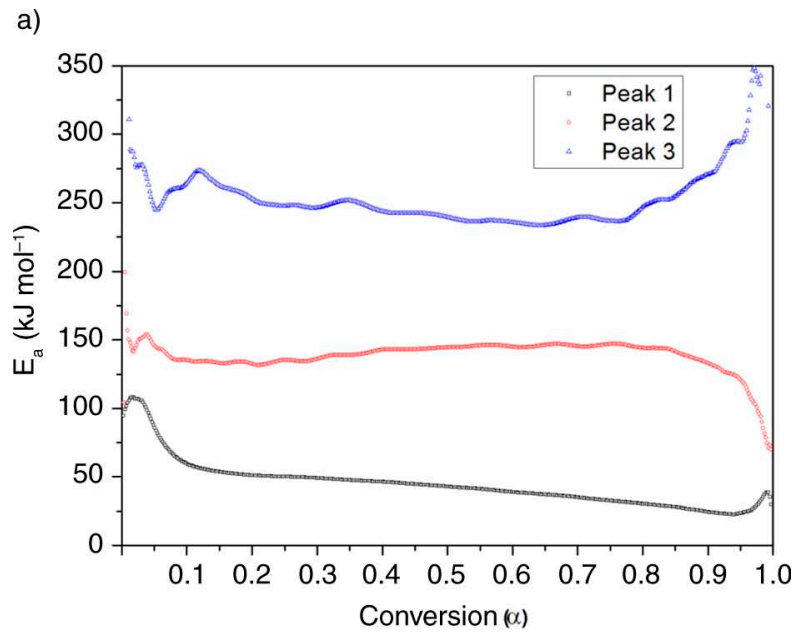

b)

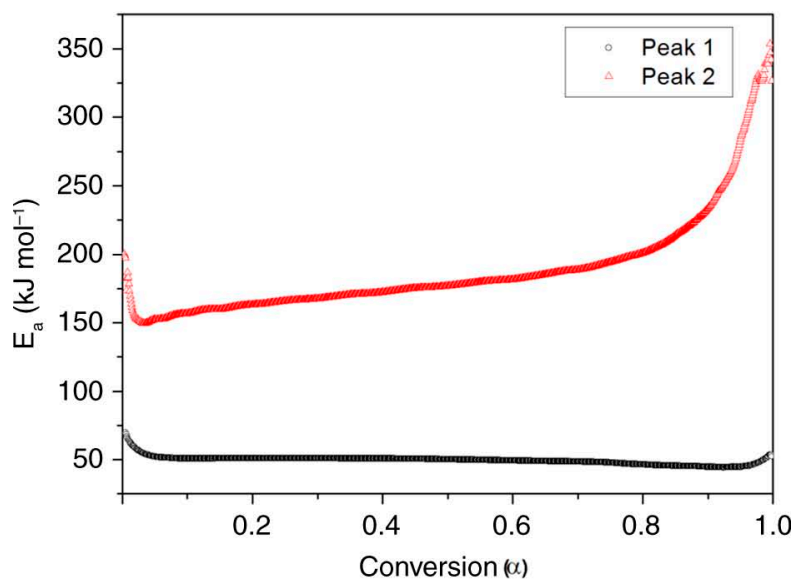

Figure 4. Apparent activation energy, as determined by the Friedman method for a) Soil S1 and b) Soil S2. 
TABLE 7. Activation energies and pre-exponential factors for $\mathrm{S} 1$ and $\mathrm{S} 2$ as determined by the Coasts-Redfern method for different $f(\alpha)$ functions

\begin{tabular}{|c|c|c|c|c|c|c|c|c|c|c|}
\hline \multirow[b]{3}{*}{ Model } & \multicolumn{6}{|c|}{ S1 } & \multicolumn{4}{|c|}{ S2 } \\
\hline & \multicolumn{2}{|c|}{$\mathrm{HgCl}_{2} \rightarrow \mathrm{Hg}(\mathrm{g})+2 \mathrm{Cl}(\mathrm{g})$} & \multicolumn{2}{|c|}{$\mathrm{HgS} \rightarrow \mathrm{Hg}(\mathrm{g})+\mathrm{S}$} & \multicolumn{2}{|c|}{$\mathrm{HgO} \rightarrow \mathrm{Hg}(\mathrm{g})+1 / 2 \mathrm{O}_{2}(\mathrm{~g})$} & \multicolumn{2}{|c|}{$\mathrm{HgCl}_{2} \rightarrow \mathrm{Hg}(\mathrm{g})+2 \mathrm{Cl}(\mathrm{g})$} & \multicolumn{2}{|c|}{$\mathrm{HgS} \rightarrow \mathrm{Hg}(\mathrm{g})+\mathrm{S}$} \\
\hline & $\begin{array}{c}E_{\mathrm{a}} \\
\left(\mathrm{kJ} \mathrm{mol}^{-1}\right)\end{array}$ & $\underset{\left(\mathrm{s}^{-1}\right)}{\mathrm{A}}$ & $\begin{array}{c}E_{\mathrm{a}} \\
\left(\mathrm{kJ} \mathrm{mol}^{-1}\right)\end{array}$ & $\underset{\left(\mathrm{s}^{-1}\right)}{\mathbf{A}}$ & $\begin{array}{c}E_{\mathrm{a}} \\
\left(\mathrm{kJ} \mathrm{mol}^{-1}\right)\end{array}$ & $\underset{\left(s^{-1}\right)}{A}$ & $\begin{array}{c}E_{\mathrm{a}} \\
\left(\mathrm{kJ} \mathrm{mol}^{-1}\right)\end{array}$ & $\underset{\left(s^{-1}\right)}{A}$ & $\begin{array}{c}E_{\mathrm{a}} \\
\left(\mathrm{kJ} \mathrm{mol}^{-1}\right)\end{array}$ & $\underset{\left(s^{-1}\right)}{A}$ \\
\hline Autocatalytic & 33.92 & $2.56 \times 10^{2}$ & 137.05 & $3.45 \times 10^{10}$ & $4.44 \times 10^{-5}$ & $1.46 \times 10^{-2}$ & 47.34 & $1.15 \times 10^{-4}$ & 176.46 & $1.06 \times 10^{14}$ \\
\hline A 1.5 & 14.99 & $3.2 \times 10^{-1}$ & 103.97 & $2.31 \times 10^{7}$ & 231.26 & $1.25 \times 10^{13}$ & 24.42 & 5.92 & 123.86 & $1.2 \times 10^{9}$ \\
\hline A2 & 7.02 & $2.17 \times 10^{-2}$ & 75.74 & $4.57 \times 10^{4}$ & 170.35 & $9.61 \times 10^{8}$ & 15.78 & $3.6 \times 10^{-1}$ & 95.07 & $2.37 \times 10^{6}$ \\
\hline An & 21.34 & 2.57 & 139.58 & $5.45 \times 10^{10}$ & $4.64 \times 10^{-5}$ & $2.61 \times 10^{3}$ & 39.51 & $6.76 \times 10^{2}$ & 173.84 & $5.19 \times 10^{13}$ \\
\hline $\mathrm{F} 1$ & 30.93 & $5.73 \times 10^{2}$ & 160.52 & $4.99 \times 10^{12}$ & 353.07 & $1.8 \times 10^{21}$ & 41.69 & $1.33 \times 10^{3}$ & 181.45 & $2.61 \times 10^{14}$ \\
\hline $\mathrm{F} 2$ & 66.43 & $1.02 \times 10^{7}$ & 272.63 & $3.54 \times 10^{23}$ & 601.04 & $1.27 \times 10^{28}$ & 78.90 & $2.68 \times 10^{8}$ & 295.76 & $1.82 \times 10^{25}$ \\
\hline F3 & 101.93 & $1.82 \times 10^{12}$ & 384.83 & $2.51 \times 10^{34}$ & 849 & $8.92 \times 10^{54}$ & 116.10 & $5.17 \times 10^{13}$ & 410.08 & $1.26 \times 10^{36}$ \\
\hline Fn & 44.43 & $5.69 \times 10^{3}$ & 151.39 & $6.67 \times 10^{11}$ & 359.16 & $4.66 \times 10^{21}$ & 53.22 & $5.8 \times 10^{4}$ & 187.76 & $1.04 \times 10^{15}$ \\
\hline $\mathrm{R} 2$ & 13.18 & $6.79 \times 10^{-2}$ & 104.32 & $9.36 \times 10^{6}$ & 229.09 & $3.39 \times 10^{12}$ & 23.09 & 1.49 & 124.29 & $4.94 \times 10^{8}$ \\
\hline R3 & 19.09 & $3.4 \times 10^{-1}$ & 123.02 & $4.02 \times 10^{8}$ & 270.42 & $1.45 \times 10^{15}$ & 29.29 & 7.6 & 143.34 & $2.11 \times 10^{10}$ \\
\hline $\mathrm{Rn}$ & 44.43 & $-2.16 \times 10^{3}$ & 151.39 & $5.37 \times 10^{10}$ & 359.16 & $-1.14 \times 10^{20}$ & 53.22 & $-1.8 \times 10^{4}$ & 187.76 & $-5.73 \times 10^{13}$ \\
\hline $\mathrm{P} 2$ & -21.76 & $1.23 \times 10^{-6}$ & -14.75 & $8.24 \times 10^{-5}$ & - & $2.4 \times 10^{-5}$ & -14.34 & $1.92 \times 10^{-5}$ & 2.83 & $4.29 \times 10^{-3}$ \\
\hline P3 & -27.49 & $1.62 \times 10^{-7}$ & -35.74 & $7.3 \times 10^{-7}$ & -74.99 & $1.98 \times 10^{-8}$ & -20.62 & $2.28 \times 10^{-6}$ & -18.61 & $3.77 \times 10^{-5}$ \\
\hline P4 & -30.357 & $5.38 \times 10^{-8}$ & -46.24 & $6.31 \times 10^{-8}$ & -97.51 & $5.21 \times 10^{-10}$ & -23.75 & $7.23 \times 10^{-7}$ & -29.33 & $3.25 \times 10^{-6}$ \\
\hline D1 & 29.80 & $1.1 \times 10^{1}$ & 174.15 & $2.56 \times 10^{13}$ & 375.26 & $1.44 \times 10^{22}$ & 42.15 & $4.15 \times 10^{2}$ & 195.75 & $1.43 \times 10^{15}$ \\
\hline D2 & 43.24 & $5.59 \times 10^{2}$ & 217.57 & $2.1 \times 10^{17}$ & 470.55 & $2.24 \times 10^{28}$ & 56.31 & $2.25 \times 10^{4}$ & 239.89 & $1.14 \times 10^{19}$ \\
\hline D3 & 61.52 & $6.23 \times 10^{4}$ & 275.20 & $1.74 \times 10^{22}$ & 598 & $2.26 \times 10^{36}$ & 75.45 & $2.63 \times 10^{6}$ & 298.62 & $9.35 \times 10^{23}$ \\
\hline D4 & 49.68 & $1.11 \times 10^{3}$ & 237.80 & $4.19 \times 10^{18}$ & 515.35 & $5.47 \times 10^{30}$ & 63.05 & $4.52 \times 10^{4}$ & 260.51 & $2.27 \times 10^{20}$ \\
\hline
\end{tabular}

The $E_{a}$ of each reaction was greater for S2 than for $\mathrm{S} 1$, in agreement with the quantity of $\mathrm{Hg}$ in each soil.

Employing equation (9), the Coast-Redfern method was also used to determine the $E_{a}$ values for all the $f(\alpha)$ functions listed in Table 2 at a constant heating rate. Table 7 shows the $E_{a}$ and $A$ values for $\mathrm{S} 1$ and $\mathrm{S} 2$ at a constant heating rate of $10^{\circ} \mathrm{C} \mathrm{min}^{-1}$.

Table 8 summarises $E_{a}$ and $A$ values and the thermal degradation mechanisms determined by the CoatsRedfern method. The thermal desorption of $\mathrm{HgCl}_{2}$ is likely to be of the $\mathrm{F}_{\mathrm{n}}$ type since this mechanism has an $E_{a}\left(44.4 \mathrm{~kJ} \mathrm{~mol}^{-1}\right.$ for $\mathrm{S} 1$ and $53.2 \mathrm{~kJ} \mathrm{~mol}^{-1}$ for S2), similar to that obtained by the FR method $\left(44.6 \mathrm{~kJ} \mathrm{~mol}^{-1}\right.$ for S1 and $49.7 \mathrm{~kJ} \mathrm{~mol}^{-1}$ for S2). The thermal degradation mechanism of $\mathrm{HgS}$ is probably $\mathrm{A}_{\mathrm{n}}$-type $(\mathrm{n}=1.1)$ for $\mathrm{S} 1$ and $\mathrm{F}_{\mathrm{n}}(\mathrm{n}=1.06)$ for $\mathrm{S} 2$. The thermal degradation mechanism of $\mathrm{HgCl}_{2}$ is $\mathrm{F}_{\mathrm{n}}$-type ( $\mathrm{n}=1.38$ for $\mathrm{S} 1$ and $n=1.31$ for S2). Finally, the thermal degradation mechanism of $\mathrm{HgO}$ is likely $\mathrm{A}_{\mathrm{n}}$-type $(\mathrm{n}=1.5)$.

L'vov (1999) reported an $E_{a}$ for the decomposition of pure $\mathrm{HgO}$ of $201.7 \pm 3 \mathrm{~kJ}^{a} \mathrm{~mol}^{-1}$ in an $\mathrm{O}_{2}$ atmosphere, and of $93 \pm 8 \mathrm{~kJ} \mathrm{~mol}^{-1}$ in a vacuum. Later, L'vov et al. (2004) reported a value of $186 \pm 1 \mathrm{~kJ} \mathrm{~mol}^{-1}$ in $\mathrm{O}_{2}$. The literature appears to have no information on the decomposition energies of $\mathrm{HgCl}_{2}$ and $\mathrm{HgS}$.

\section{CONCLUSIONS}

The $E_{a}$ was found to be practically constant over the 0.1-0.9 $\alpha$ interval for S1 and S2, suggesting that the decomposition of $\mathrm{Hg}$ compounds

TABLE 8. Activation energies of S1 and S2 as obtained by the Coats-Redfern method

\begin{tabular}{|c|c|c|c|c|}
\hline Peak/Reaction & & $\begin{array}{c}E_{\mathrm{a}} \\
\left(\mathrm{kJ} \mathrm{mol}^{-1}\right)\end{array}$ & $\underset{\left(\mathbf{s}^{-1}\right)}{\mathrm{A}}$ & $\begin{array}{c}\text { Thermal decomposition } \\
\text { mechanism }\end{array}$ \\
\hline $\begin{array}{l}\text { Peak 1: } \\
\mathrm{HgCl}_{2} \rightarrow \mathrm{Hg}(\mathrm{g})+2 \mathrm{Cl}(\mathrm{g})\end{array}$ & $\begin{array}{l}\text { S1 } \\
\text { S2 }\end{array}$ & $\begin{array}{l}44.4 \\
53.2\end{array}$ & $\begin{array}{l}5.69 \times 10^{3} \\
5.80 \times 10^{4}\end{array}$ & $\begin{array}{l}\text { Fn: }(1-\alpha)^{1.38}(n=1.38) \\
\text { Fn: }(1-\alpha)^{1.31}(n=1.31)\end{array}$ \\
\hline $\begin{array}{l}\text { Peak } \\
2: \mathrm{HgS} \rightarrow \mathrm{Hg}(\mathrm{g})+\mathrm{S}(\mathrm{g})\end{array}$ & $\begin{array}{l}\text { S1 } \\
\text { S2 }\end{array}$ & $\begin{array}{l}139.6 \\
187.8\end{array}$ & $\begin{array}{l}5.45 \times 10^{10} \\
1.04 \times 10^{15}\end{array}$ & $\begin{array}{l}A_{n}=n(1-\alpha)\left[-\ln (1-\alpha)^{(1-1 / n)}(n=1.1)\right. \\
\text { Fn: }(1-\alpha)^{n}(n=1.06)\end{array}$ \\
\hline $\begin{array}{l}\text { Peak } \\
\text { 3: } \mathrm{HgO} \rightarrow \mathrm{Hg}(\mathrm{g})+1 / 2 \mathrm{O}_{2}(\mathrm{~g})\end{array}$ & $\begin{array}{l}\text { S1 } \\
\text { S2 }\end{array}$ & $\begin{array}{c}231.3 \\
-\end{array}$ & $\begin{array}{c}1.25 \times 10^{13} \\
-\end{array}$ & $\mathrm{A}_{\mathrm{n}}=\mathrm{n}(1-\alpha)\left[-\ln (1-\alpha)^{(1-1 / \mathrm{n})}(\mathrm{n}=1.5)\right.$ \\
\hline
\end{tabular}


is a single-step process with an $E$ of $44-53.2$ $\mathrm{kJ} \mathrm{mol}{ }^{-1}$ for $\mathrm{HgCl}_{2}, 139.6-187.8 \mathrm{~kJ} \mathrm{~mol}^{-1}$ for $\mathrm{HgS}$, and $231 \mathrm{~kJ} \mathrm{~mol}^{-1}$ for $\mathrm{HgO}$. The corresponding $E_{a}$ and $A$ values were calculated in order to interpret the relationships between the soils. The Coats-Redfern method was successfully used to predict the reaction mechanism of thermal degradation of $\mathrm{Hg}$ compounds. The decomposition reaction model for $\mathrm{HgCl}_{2}$ is first order, whereas that of $\mathrm{HgO}$ is described by the AvaraniErofe've model, and that of $\mathrm{HgS}$ is first order and also described by the Avarani-Erofe've model, depending on the soil type. Knowledge of these $E_{a}$ values could be important when attempts are made to remediate $\mathrm{Hg}$-contaminated soils by thermal decomposition.

\section{ACKNOWLEDGMENTS}

This work was funded by MAYASA and the Centro Tecnológico Nacional para la Descontaminación del Mercurio (CTNDM).

Dr. O. Rodríguez is the recipient of contract JAE-Doc_09-00121 (CSIC), co-funded under the FSE 2007-2013 Multiregional Adaptability and Employment Operational Programme.

\section{NOMENCLATURE}

\author{
DSC: Differential Scanning Calorimetry \\ $E$ : Activation energy $\left(\mathrm{kJ}_{\mathrm{mol}}{ }^{-1}\right)$ \\ $d H / d t$ : Heat flow $(\mathrm{mW})$ \\ $E_{a}$ : Apparent activation energy at $\alpha\left(\mathrm{kJ} \mathrm{mol}^{-1}\right)$ \\ $A$ : Pre-exponential factor $\left(\mathrm{s}^{-1}\right)$ \\ $\alpha$ : conversion \\ $\mathrm{n}$ and $\mathrm{m}$ : reaction order \\ $\mathrm{R}$ : gas constant $\left(\mathrm{J} \mathrm{mol}^{-1} \mathrm{~K}^{-1}\right)$ \\ T: Temperature $\left({ }^{\circ} \mathrm{C}\right)$ \\ $\mathrm{T}_{\mathrm{m}}$ : Maximum temperature peak $\left({ }^{\circ} \mathrm{C}\right)$ \\ $\beta$ : Heating rate $\left({ }^{\circ} \mathrm{C} \mathrm{min}^{-1}\right)$ \\ $f(\alpha)$ : Functions of conversion \\ $g(\alpha)$ : Integral function of conversion
}

\section{REFERENCES}

Aboulkas, A., El Harfi, K., El Bouadili, A. 2010. Thermal degradation behaviors of polyethylene and polypropylene. Part I: Pyrolysis kinetics and mechanisms. Energ. Convers. Manage. 51 (7), 1363-1369. http://dx.doi.org/10.1016/j. enconman.2009.12.017.

Adriano, D.C. 2001. Chapter 11. Mercury. Trace Elements in the Terrestrial Environments. 2nd Edition ed. New York: Springer; 2001. pp. 411-458.

Biester, H., Gosar, M., Covelli, S. 2000. Mercury speciation in sediments affected by dumped mining residues in the drainage area of the Idrija mercury mine, Slovenia. Environ. Sci. Technol. 34 (16), 3330-3336. http://dx.doi.org/10.1021/es991334v.

Coats, A.W., Redfern, J.P. 1964. Kinetic parameters from thermogravimetric data. Nature 201 (491), 68-70. http://dx.doi. org/10.1038/201068a0.
Chang, T.C., Yen, J.H. 2006. On-site mercury-contaminated soilsremediation by using thermal desorption technology. J. Hazard. Mater. 128 (2-3), 208-217. http://dx.doi. org/10.1016/j.jhazmat.2005.07.053.

Doyle, C.D. 1961. Kinetic analysis of thermogravimetric data. J. Appl. Polym. Sci. 5 (15), 285-292. http://dx.doi. org/10.1002/app.1961.070051506.

Egler, S.G., Rodrigues, S., Villas-Boas, R.C., Beinhoff, C. 2006. Evaluation of mercury pollution in cultivated and wild plants from two small communities of the Tapajo's gold mining reserve, Para State, Brazil. Sci. Total. Environ. 368 (1), 424 433. http://dx.doi.org/10.1016/j. scitotenv.2005.09.037.

Fitzgerald, W.F., Lamborg, C.H. 2003. Treatise on Geochemistry, Ed. Elsevier, Oxford (UK), pp. 107-148.

Flynn, J.H., Wall, L.A. (1966). A quick direct method for determination of activation energy from thermogravimetric data. J. Polym. Sci. Pol. Lett. 4 (5PB), 323-327. http:// dx.doi.org/10.1002/pol.1966.110040504.

Friedman, H.L. 1964. Kinetics of thermal degradation of charforming plastics from thermogravimetry. Applications to phenolic plastic. J. Polym. Sci. Pol. Sym. (6PC), 183-195.

Gaona Martínez, X. 2004. El mercurio como contaminante global. Desarrollo de metodologías para su determinación en suelos contaminados y estrategias para la reducción de su liberación al medio ambiente. Barcelona, Universidad Autónoma de Barcelona.

Gochfeld, M. 2003. Cases of mercury exposure, bioavailability, and absorption. Ecotoxicol. Environ. Saf. 56 (1), 174-179. http://dx.doi.org/10.1016/s0147-6513(03)00060-5.

Higueras, P., Oyarzun, R., Biester, H., Lillo, J., Lorenzo, S. 2003. A first insight into mercury distribution and speciation in soils from the Almaden mining district, Spain. J. Geochem. Explor. 80 (1), 95-104. http://dx.doi.org/10.1016/ s0375-6742(03)00185-7.

Hylander, L.D., Meili, M. 2003. 500 years of mercury production: global annual inventory by region until 2000 and associated emissions. Sci. Total. Environ. 304 (1-3), 13-27. http://dx.doi.org/10.1016/s0048-9697(02)00553-3.

Karathanasis, A.D., Harris, W.G. 1994. Quantitative Methods in Soil Mineralogy, Ed. Soil Science Society of America, Madison WI, pp. 360-411.

Kunkel, A.M., Seibert, J.J., Elliott, L.J., Kelley, R., Katz, L.E., Pope, G.A. 2006. Remediation of elemental mercury using in situ thermal desorption (ISTD). Environ. Sci. Technol. 40 (7), 2384-2389. http://dx.doi.org/10.1021/es0503581.

L'Vov, B.V., Ugolkov, V.L., Grekov, F.F. 2004. Kinetics and mechanism of free-surface vaporization of zinc, cadmium and mercury oxides analyzed by the third-law method. Thermochim. Acta. 411 (2), 187-193. http://dx.doi.org/10.1016/j. tca.2003.08.024

Liu, G.L., Cabrera, J., Allen, M., Cai, Y. 2006. Mercury characterization in a soil sample collected nearby the DOE Oak Ridge Reservation utilizing sequential extraction and thermal desorption method. Sci. Total. Environ. 369 (1-3), 384 392. http://dx.doi.org/10.1016/j.scitotenv.2006.07.011.

Lopez-Anton, M.A., Yuan, Y., Perry, R., Maroto-Valer, M.M. 2010. Analysis of mercury species present during coal combustion by thermal desorption. Fuel. 89 (3), 629-634. http://dx.doi.org/10.1016/j.fuel.2009.08.034.

López-Delgado, A., López, F.A., Alguacil, F.J., Padilla, I., Guerrero, A. 2012a. A microencapsulation process of liquid mercury by sulfur polymer stabilization/solidification technology. Part I: Characterization of Materials. Rev. Metal. 48 (1), 45-57. http://dx.doi.org/ 10.3989/ revmetalm.1133.

López-Delgado, A., Guerrero, A., López, F.A., Pérez, C., Alguacil, F.J. 2012b. A microencapsulation process of liquid mercury by sulfur polymer stabilization/solidification technology. Part II: Durability of Materials. Rev. Metal. 48 (1), 58-66. http://dx.doi.org/10.3989/revmetalm.1137.

Loveday, J., Beatty, H.J., Norris, J.M. 1972. Comparison of current chemical methods for evaluating irrigation soils. CSIRO Australia, Division of Soils, Technical Paper 14. 
MAPA. 1994. Métodos oficiales de Análisis: Tomo III. (Ministerio de Agricultura, Pesca y Alimentación). Madrid (Spain): Secretaría General Técnica.

Millan, R., Gamarra, R., Schmid, T., Sierra, M.J., Quejido, A.J., Sanchez, D.M., Cardona, A.I., Fernandez, A., Vera, R. 2006. Mercury content in vegetation and soils of the Almaden mining area (Spain). Sci. Total. Environ. 368 (1), 79-87. http://dx.doi.org/10.1016/j.scitotenv.2005.09.096.

Millan, R., Schmid, T., Sierra, M.J., Carrasco-Gil, S., Villadoniga, M., Rico, C., Ledesma, D.M.S., Puente, F.J.D. 2011. Spatial variation of biological and pedological properties in an area affected by a metallurgical mercury plant: Almadenejos (Spain). Appl. Geochem. 26 (2), 174-181. http://dx.doi. org/10.1016/j.apgeochem.2010.11.016.

Oliveira, L.C., Botero, W.G., Santos, F.A., Jr., É.S., Rocha, J.C., Santos, A. 2012. Influence of Seasonality on the Interaction of Mercury with Aquatic Humic Substances Extracted from the Middle Negro River Basin (Amazon). J. Braz. Chem. Soc. 23 (9), 1711-1718. http://dx.doi.org/ S0103-505320120050000034.

Ozaki, M., Uddin, M.A., Sasaoka, E., Wu, S.J. 2008. Temperature programmed decomposition desorption of the mercury species over spent iron-based sorbents for mercury removal from coal derived fuel gas. Fuel. 87 (17-18), 36103615. http://dx.doi.org/10.1016/j.fuel.2008.06.011

Ozawa, T., 1965. A new method of analizing thermogravimetric data. Bull. Chem. Soc. Jpn. 38 (11), 1881-1884. http:// dx.doi.org/10.1246/bcsj.38.1881.

Page, A.L., Miller, R.H. Heeney, D. R. 1987. Methods of soil analysis. Part 2. Chemical and microbiological properties. Ed. American Society of Agronomy, Soil Science Society of America. Madison, Wisconsin (USA)

Paruchuri, Y., Siuniak, A., Johnson, N., Levin, E., Mitchell, K., Goodrich, J.M., Renne, E.P., Basu, N. 2010. Occupational and environmental mercury exposure among small-scale gold miners in the Talensi-Nabdam District of Ghana's Upper East region. Sci. Total. Environ. 408 (24), 6079-6085. http://dx.doi.org/10.1016/j. scitotenv.2010.08.022
Plante, A.F., Fernández, J.M., Leifeld, J. 2009. Application of thermal analysis techniques in soil science. Geoderma. 153 (1-2), 1-10. http://dx.doi.org/10.1016/j.geoderma.2009.08.016

Salgado, J., González, M.I., Armada, J., Paz-Andrade, M.I., Carballas, M., Carballas, T. 1995. Loss of organic matter in Atlantic forest soils due to wildfires. Calculation of the ignition temperature. Thermochim. Acta. 259 (1), 165-175. http://dx.doi.org/10.1016/0040-6031(95)02274-6.

Salgado, J., Mato, M.M. Vázquez-Galiñanes, A., Paz-Andrade, M.I., Carballas, T. 2004. Comparison of two calorimetric methods to determine the loss of organic matter in Galician soils (NW Spain) due to forest wildfires. Thermochim. Acta. 410 (1-2), 141-148. http://dx.doi.org/10.1016/ S0040-6031(03)00400-3

Skyllberg, U., Bloom, P.R., Qian, J., Lin, C.M., Bleam, W.F. 2006. Complexation of mercury(II) in soil organic matter: EXAFS evidence for linear two-coordination with reduced sulfur groups. Environ. Sci. Technol. 40 (13), 4174- 4180. http://dx.doi.org/10.1021/es0600577.

Stein, E.D., Cohen, Y., Winer, A.M. 1996. Environmental distribution and transformation of mercury compounds. Crit. Rev. Environ. Sci. Technol. 26 (1), 1-43.

USEPA. 1996. Method 3052. Washington D.C.: EPA Office of Solid Waste.

USEPA. 2008. Land disposal restrictions: Regulations for mercury-containing non waste waters. R 40CFR Part 273.

Vyazovkin, S. 2001. Modification of the integral isoconversional method to account for variation in the activation energy. J. Comput. Chem. 22 (2) 178-183. http:/l dx.doi.org/10.1002/1096-987x(20010130)22:2<178::aidjcc5>3.0.co;2-\#.

Wang, J.X., Feng, X.B., Anderson, C.W.N., Xing, Y., Shang, L.H. 2012. Remediation of mercury contaminated sites - A review. J. Hazard. Mater. 221, 1-18. http://dx.doi. org/10.1016/j.jhazmat.2012.04.035.

Windmoller, C.C., Wilken, R.D., Jardim, W.D. 1996. Mercury speciation in contaminated soils by thermal release analysis. Water. Air. Soil. Poll. 89 (3-4), 399-416. http://dx.doi. org/10.1007/bf00171644 